\title{
A Comparison of Temporal Life Satisfaction of Nursing Students in the Republic of Croatia and the Republic of Bulgaria
}

1 Denis Toma

2 Yulia Chusova

1 Mara Županić

1 University of Applied Health Sciences, Zagreb, Croatia

2 Specialities Medical University of Varna, Varna, Bulgaria

Article received: 07.11.2019.

Article accepted: 17.03.2020.

DOI: $10.24141 / 2 / 4 / 1 / 9$

Author for correspondence:

Mara Županić

University of Applied Health Sciences

Mlinarska cesta 38, Zagreb, Croatia

E-mail: mara.zupanic@zvu.hr

Keywords: temporal satisfaction with life, nursing students, place of studying

\section{Abstract}

Introduction. Temporal satisfaction with life can be defined as satisfaction of an individual with their past, present and future life. When conducting a classic study of satisfaction with life, the focus is placed on different periods in life in order to avoid a poten- tial error in measuring satisfaction with life. Closely connected to the concept of satisfaction with life is the concept of happiness, which represents a momentary, passing experience. Although it is pleasant, it can last for a shorter or longer time period. Satisfaction with life is a much more complex concept. Many authors define it as a general feeling or opinion about the life of an individual. There are a number of factors from different areas of life that contribute to satisfaction with life. They include work, romantic relationships, relations with family and friends, personal growth and health, among others. The measures of satisfaction with life are generally subjective or they are based on variables that an individual considers especially important in their own life.

Aim. The aim is to question and compare the differences in temporal satisfaction with life among nursing students in Croatia and Bulgaria.

Methods. The study included 100 nursing students, out of which 50 students are studying in the Republic of Croatia and 50 in the Republic of Bulgaria. The study used a questionnaire as an instrument of research. The questionnaire was The Temporal Satisfaction with Life Scale (hereinafter TSWLS), which was devised in 1998 by Pavot and associates.

Results. A statistically significant difference was found in 9 out of 15 statements. Furthermore, a statistically noticeable difference is seen in the average evaluation of overall temporal satisfaction with life between Croatian and Bulgarian nursing students.

Conclusion. The study determined statistically significant differences in temporal satisfaction with life amongst students of nursing from Croatia and Bulgaria. 


\section{Introduction}

A small number of papers deals with the topic of temporal satisfaction with life, which can be concluded through an overview of the available bibliography. The World Health Organization (WHO) has defined satisfaction with life as the possibility of a person to achieve their goals, expectations, standards and interests in a way that is appropriate to their cultural system and values. Many authors connect the concept of temporal satisfaction with life with other concepts such as quality of life and happiness. Besides the definition given by $\mathrm{WHO}$, there are a number of other definitions provided by other authors.

The International Wellbeing Group has defined the quality of life as a multidimensional construct that includes the standard of living, health, productivity, the ability to make close contacts, a current feeling of security, a feeling of security for the future and a feeling of belonging in the community (1). In 1984 Ed Diener provided a definition that has been used in interpreting many research papers. He defines satisfaction with life as an overall assessment of feelings and attitudes about an individual's life in a particular moment. Feelings and attitudes are ranked from negative to positive ones. Furthermore, the theory studies the negative and positive influence of feelings and attitudes on satisfaction with life. Although satisfaction with current life circumstances is often evaluated in research studies, Diener and his associates also include the following in satisfaction with life: the desire to change someone's life; satisfaction with the past; satisfaction with the future; and significant outlooks on someone's life. Connected terms in bibliography include happiness (which is sometimes regarded as satisfaction with life), quality of life and a subjective or psychological wellbeing, which is a wider concept than that of satisfaction with life (2). Another definition was provided by Ruut Veenhoven. He claims that satisfaction with life is the degree to which a person positively rates the quality of their life as a whole. In other words, how much a person loves the life he or she leads (according to 3 ). In some of his research, the author deals with the empirical studies of connections between happiness and quality of life. The author claims that the quality of life is envisioned as a broad term that includes three units: the quality of the environment in which the individual lives, ways of confrontation and subjective enjoyment of life. Furthermore, happiness is implied as being part of the latter meaning. It is defined as an overall evaluation of an individual's life as a whole. By reviewing studies on the topic of happiness, it can be concluded that happiness is most influenced by the environment, especially economic wealth, freedom and close relations. The studies also show a relation between happiness and ways of confrontation that are mostly influenced by physical and mental health.

Gokcen Akyurek, Aysegul Efe \& Esra Aki (2019) conducted a study entitled Psychometric properties of the Temporal Satisfaction with Life Scale among Turkish people. Its aim was to adapt the Scale of Temporal Satisfaction with Life to the Turkish language and to explore reliability and validity of the new Turkish version of the scale (4). Considering the central role of satisfaction with life not only for individual but also social wellbeing, a valid evaluation of satisfaction with life has become a main concern and primary challenge for researching quality of life. This makes the cultural adaptation of the scale valuable in order to provide an assessment of temporal factors in an individual's satisfaction with life while taking into account the past, present and future. The study was conducted in four phases with 236 participants who were randomly chosen. There were 113 women and 123 men. Taking into account the fact that the scale had a high level of language equivalence, other studies were also conducted and questioned reliability and validity. To conclude, the results confirm that TSWLS is a valid and reliable measure of temporal satisfaction with life. The authors claim that researchers can rely on the Turkish version of the scale (5).

Zlopaša and Dremel (2017) conducted a study entitled Satisfaction with life: a sociological outlook based on the example of Jamaican students. The study was conducted on a non-representative number of students of The University of West Indies, located in Kingston, the capital of Jamaica. By using the method of a survey, the study involved 73 students. Out of the total number, $44 \%$ were women and $56 \%$ were men. The minimal age was 18 and the maximum was 36. Alongside the survey method, three semi-structured interviews with female students of The University of West Indies were conducted. This study tried to demonstrate the subjective satisfaction with life among students of different courses and years of study. Furthermore, the participants 
assessed their satisfaction in relation to the standard of living, health, life accomplishments, relations with family and friends, a feeling of belonging to the community and security from financial problems in the future. An analysis of the collected data showed a connection between satisfaction with life, taking into account satisfaction with the standard of living, satisfaction with health, satisfaction with life accomplishments and satisfaction with their relations with family and friends (6).

Although focusing on youth problems is highly important, in recent time there has been a greater focus on the importance of promoting optimal levels of health in adolescents and pointing towards positive indicators of wellbeing. Among those indicators, satisfaction with life is definitely the most important one. The importance of satisfaction with life in adolescents has been widely researched. Studies have shown that individual differences in satisfaction with life in adolescents can predict important life outcomes (7).

One of the studies conducted in Croatia took place in 2006. It was conducted in Zadar, Split, Šibenik and
Sinj on an appropriate sample of subjects of different ages. Groups of high school students and university students were questioned in groups, while younger adults who are not students, middle aged people and older people were contacted individually. In the study (Penezić, 2006), the main aim was to attempt to specify the differences between satisfaction with life in different age groups. Assessments of previous satisfaction were the lowest among middle-aged people, while the expected satisfaction with future life was highest in younger adolescents. A newer study aimed to question temporal satisfaction with life in two groups similar in age but with a different place of study (8).

Temporal satisfaction with life can be defined as an individual's satisfaction with their past, present or future life. In order to reduce a potential error in measuring satisfaction with life, classic research focuses on different periods of life. A measuring instrument (TSWLS) is used to distinguish the difference between satisfaction with past, present and future life. Including the temporal perspective helps the participants to focus on a specific time frame or, in

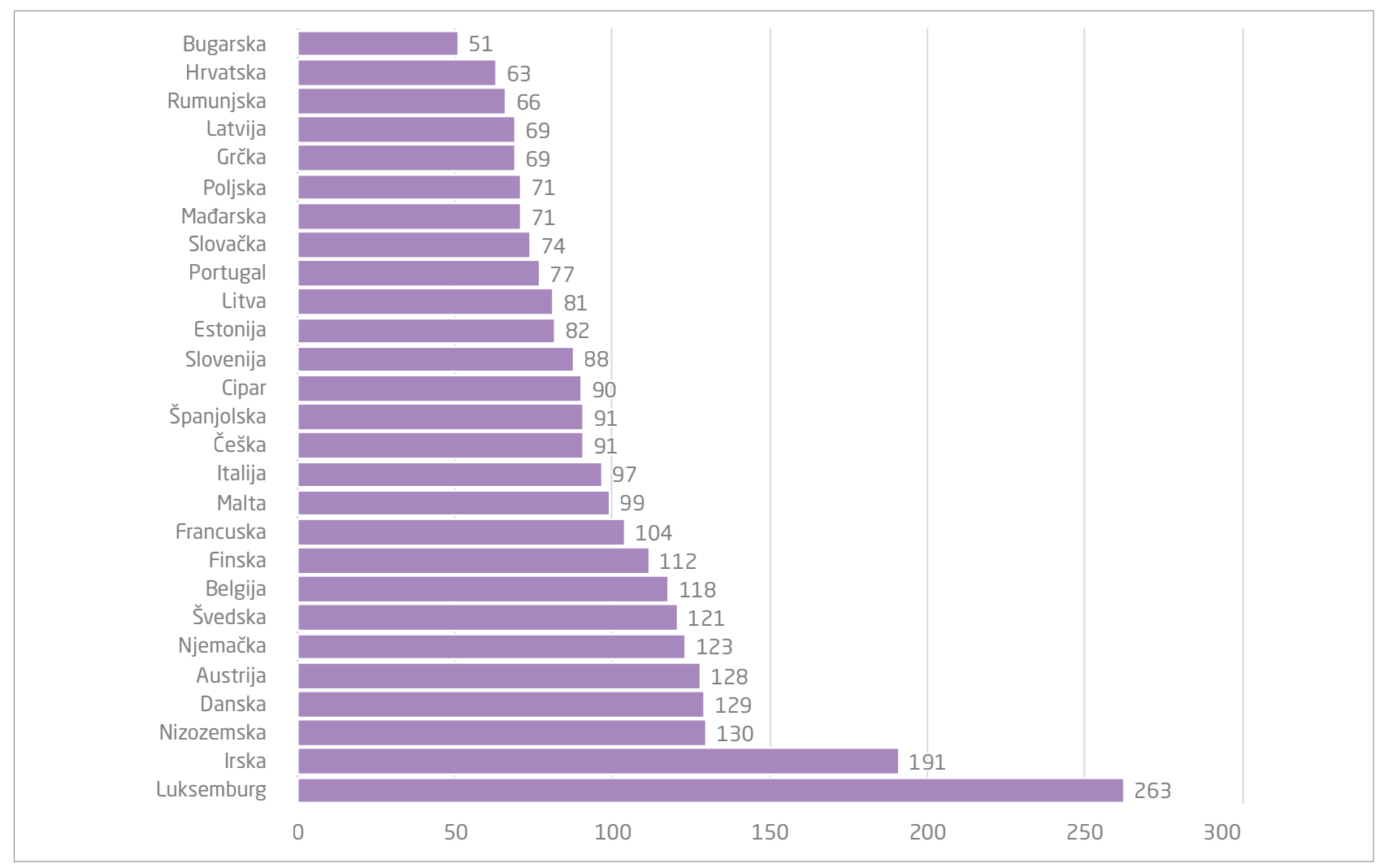

Chart 1. GNP per capita shown in PPS

(https://europa.eu/european-union/about-eu/figures/living_hr\#quality_of_life) 
other words, on their satisfaction with a specific time frame. The standard of living has a great influence on satisfaction with life.

The standard of living can be compared by measuring the price of certain goods and services with regard to income by using a common fictional currency called the Purchasing Power Standard (PPS). By comparing GNP per capita, shown in PPS, an overview of the standard of living in countries of the European Union is obtained (9).

The Republic of Croatia and the Republic of Bulgaria are ranked 26 and 27 on the European Union's list of GNP (as shown in chart 1). Although Croatia has a larger GNP according to Eurostat data, Bulgaria is immediately behind. This is the reason why the researched data comes from these two countries.

The aim of the study is to examine and compare the difference in temporal satisfaction with life in nursing students from Croatia and Bulgaria.

\section{Methods}

The study was conducted in July, August and September of 2019. It included 100 nursing students from different institutions from each country and from different years of study. The research was conducted by using an on-line questionnaire. The main purpose was to examine temporal satisfaction with life in nursing students in connection with the place where they are studying. The measuring instrument was the Scale of Temporal Satisfaction with Life (hereinafter TSWLS), devised by Pavot in 1998, in a Croatian and a Bulgarian version. It was filled out by 50 nursing students from Croatia and 50 nursing students from Bulgaria. All of the participants were familiar with the aim of the research, and it was explained to them that their participation was voluntary and anonymous. The average time needed to fill out the questionnaire was 5 minutes.

It has been proven that TSWLS has favourable psychometric features such as a high inner consistency and high temporal reliability. The results of the scale are moderately to moderately highly connected to other measures of subjective wellbeing, and they can be predicted to match specific personality traits. It has been noticed that TSWLS can be used in different age groups, and other potential uses of the scale are being researched. The scale's level of reliability in this study conducted on a student population is $\alpha=87$. By expanding the study, the scale was also found highly reliable on a population of people in late adulthood (10). TSWLS includes a time frame, and the participants are asked to give grades that refer to the past, present and future satisfaction. The first part of the questionnaire consisted of 5 general demographic questions (age, sex, nationality, year of study and the name of university). The second part consisted of 15 claims which had answers in the form of the Likert scale. In this scale, 1 represents the claim "I do not agree at all", 2: "This mostly does not apply to me", 3: "This neither applies nor does not apply to me", 4: "This usually applies to me", and 5: "This completely applies to me". The first 5 claims are concerned with the past, claims 6 through 10 with current satisfaction and claims 11 through 15 with future satisfaction. A higher number of total points shows a higher temporal satisfaction with life of the participants. A high grade shows a higher level of satisfaction with life.

\section{Results}

The participants of the research were 100 nursing students, out of whom $84 \%$ were women and $16 \%$ men. The division of sexes in regard to the country in which they are studying is shown in chart 2 . The age range of Bulgarian students was from 18 to 43 $(M=24, S D=4.9)$. The age range of Croatian students was from 19 to $26(M=22, S D=1.5)$. The age difference between the two groups was statistically significant ( $\mathrm{t}=2.77 ; p=0.007)$.

Table 1 shows the data of the arithmetic mean (M), the standard deviation (SD), the dominant value, the t-value and the $p$-value. Furthermore, the table shows the results for the claims. Among the five claims that deal with satisfaction with the past, Croatian students gave the highest grades for the claim "I am happy with my past" (M=3.74), while the claim "If I were to live my life again, I would not change 


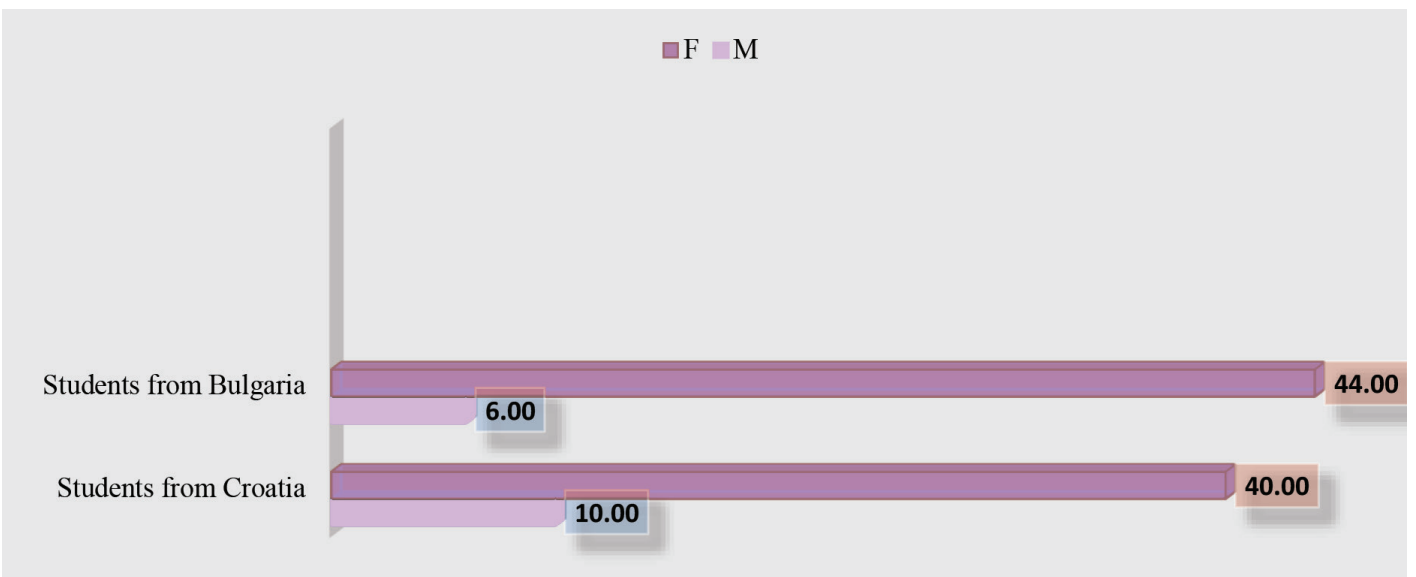

Chart 2. Division of sexes with regard to the place of study

anything" received the lowest grade (M=3.22). Out of the claims that deal with the present, the highest grades were given to the claims "I am happy with my present life" and "I currently have all the things that are important to me" $(M=4.06)$. The lowest grades were given to the claim "I would not change anything in my present life" ( $M=3.46)$. Among the five claims concerned with the future, the Croatian students gave the highest grades to the claim "I will be happy with my future life" ( $M=4.1)$, which points to the suggestion that they will make changes about their current life because the claim "I will not change anything about my life in the future" received the lowest grades $(M=2.44)$. Taking into account their overall satisfaction with future life, Croatian students are not as optimistic as Bulgarian students. Among the five claims that deal with satisfaction with the past, the Bulgarian students gave the highest grades to the claim "I am happy with my past" $(M=4.2)$, while the claim "My past was almost ideal to me" received the lowest grades $(M=3.46)$. Among the claims that deal with the present, the highest grades were given to the claim "I am happy with my present life" ( $M=4.46)$. The lowest grades were given to the claim "My current life situation is excellent" ( $M=3.38)$. The overall situation shows that Bulgarian students are more optimistic than Croatian students. Among the five claims that deal with the future, the highest grades were given to the claim "I will have all the important things that I want in the future" $(M=4.26)$. The students will also make an effort to change a lot of things because the claim "I will not change anything about my life in the future" received the lowest grades ( $M=2.66)$. The claims that have a statistically significant difference are specifically indicated $\left(^{\star}\right)$.
Table 2 shows the arithmetic means (M), standard sample deviations (SD), t-values and P-values of grades for each individual period of life or for the past, present or future lives of nursing students in the Republic of Bulgaria and the Republic of Croatia. Nursing students in Croatia gave, on average, 3.43 points of the Likert scale to the claims concerned with the past. This is 0.29 points less than the Bulgarian students, who gave, on average, 3.72 points to the claims concerned with the past. Croatian students gave higher points to their current satisfaction with life $(M=3.88)$ than Bulgarian students $(M=3.74)$. On the other hand, Bulgarian nursing students are more optimistic about their future, given the fact that their average grade for those claims $(M=3.68)$ is higher than the average grade given by Croatian nursing students ( $M=3.51)$. The total average grade of nursing students from Croatia and Bulgaria regarding the claims about satisfaction with the past is 3.58, for satisfaction with current life the grade is 3.81 and for the future it is 3.6. By conducting a t-test for large independent samples, it can be concluded that it is not a statistically significant difference, although the claims regarding the past showed the most significant difference in points or, in other words, in satisfaction.

The results in table 3 show the overall temporal satisfaction with life for Croatian and Bulgarian students. The table shows the average grade for each group of students, standard sample deviation, the tvalue and the $p$-value. 


\section{Table 1. Temporal satisfaction with life among nursing students in Croatia}

\begin{tabular}{|c|c|c|c|c|c|c|c|c|}
\hline \multirow[t]{2}{*}{ Claim } & \multicolumn{2}{|c|}{$\begin{array}{c}\text { arithmetic } \\
\text { mean (M) }\end{array}$} & \multicolumn{2}{|c|}{$\begin{array}{l}\text { standard } \\
\text { deviation } \\
\text { (SD) }\end{array}$} & \multicolumn{2}{|c|}{$\begin{array}{l}\text { Dominant } \\
\text { value }\end{array}$} & \multirow[t]{2}{*}{ t-value } & \multirow[t]{2}{*}{ p-value } \\
\hline & $\mathbf{R H}$ & RB & RH & RB & $\mathbf{R H}$ & RB & & \\
\hline If I could live my life again, I would not change anything. & 3.22 & 3.92 & 1.2 & 1.12 & $\begin{array}{l}D_{1}=3 \\
D_{2}=2\end{array}$ & 4 & 3.04 & $0.003^{\star}$ \\
\hline I am happy with my past. & 3.74 & 4.2 & 1.17 & 0.76 & 4 & 4 & 2.34 & $0.022^{*}$ \\
\hline My past was almost perfect for me. & 3.32 & 3.46 & 1.06 & 0.97 & 4 & 4 & 0.7 & 0.493 \\
\hline My life conditions in the past were excellent. & 3.3 & 3.54 & 1.11 & 1.05 & 3 & 4 & 1.1 & 0.269 \\
\hline In the past, I had important things that I wanted. & 3.58 & 3.5 & 1.09 & 1.32 & 4 & 4 & 0.33 & 0.742 \\
\hline I would not change anything in my present life. & 3.46 & 3.42 & 1.15 & 1.4 & 4 & 4 & 0.16 & 0.876 \\
\hline I am happy with my present life. & 4.06 & 4.46 & 0.74 & 0.68 & 4 & 5 & 3.45 & $0.006^{*}$ \\
\hline My present life is almost perfect. & 3.62 & 3.6 & 0.99 & 0.99 & $\begin{array}{l}D_{1}=4 \\
D_{2}=3\end{array}$ & 4 & 0 & 0.920 \\
\hline My current life conditions are excellent. & 3.86 & 3.38 & 0.86 & 1.11 & 4 & 4 & 2.4 & $0.018^{\star}$ \\
\hline I currently have all the important things I want. & 4.06 & 3.48 & 0.84 & 1.31 & 4 & 4 & 2.64 & $0.010^{\star}$ \\
\hline In the future, I will not change anything about my life. & 2.44 & 2.66 & 1.03 & 1.24 & 2 & 3 & 0.96 & 0.337 \\
\hline I will be happy with my future life. & 4.1 & 3.24 & 0.86 & 1.2 & 4 & 3 & 4.1 & $0.0001^{*}$ \\
\hline I expect my future to be perfect. & 3.64 & 4.18 & 1.06 & 0.92 & 4 & 5 & 2.74 & $0.008^{\star}$ \\
\hline In the future, my life conditions will be perfect. & 3.54 & 4.08 & 0.95 & 0.92 & 4 & 4 & 2.84 & $0.005^{*}$ \\
\hline $\mathrm{n}$ the future, I will have all the important things that I & 3.86 & 4.26 & 0.97 & 0.96 & 4 & 5 & 2.11 & $0.041^{*}$ \\
\hline
\end{tabular}

\section{Table 2. Results of the scale for temporal satisfaction with life for specific time periods for nursing} students in Croatia and Bulgaria

\begin{tabular}{cccccccc} 
& & M & & & SD & t-value & p-value \\
& CRO & BUL & CRO & BUL & . & \\
\hline Past & 3.43 & 3.72 & 1.13 & 1.13 & 1.28 & 0.203 \\
\hline Present & 3.88 & 3.74 & 0.94 & 1.82 & 0.48 & 0.630 \\
\hline Future & 3.51 & 3.68 & 1.13 & 1.17 & 0.74 & 0.462 \\
\hline
\end{tabular}

\section{Table 3. Overall temporal satisfaction with life}

\begin{tabular}{|c|c|c|c|c|}
\hline & \multicolumn{2}{|c|}{ Croatian students } & t-value & p-value \\
\hline \multirow{5}{*}{ Overall temporal satisfaction with life. } & $M$ & SD & \multirow{5}{*}{2.92} & \multirow{5}{*}{$0.004^{*}$} \\
\hline & 3.61 & 0.24 & & \\
\hline & \multicolumn{2}{|c|}{ Bulgarian students } & & \\
\hline & M & SD & & \\
\hline & 3.71 & 0.03 & & \\
\hline
\end{tabular}




\section{Discussion}

Nursing students in Croatia gave, on average, 3.43 points to claims concerned with the past, while the Bulgarian students gave, on average, 3.72 points to those claims. By doing a t-test for large independent samples, it can be concluded that it is not a statistically significant difference, although the claims regarding the past showed the most significant difference in points or, in other words, in satisfaction. Croatian students gave higher points to current satisfaction with life $(M=3.88)$ than did Bulgarian students $(M=3.74)$. On the other hand, Bulgarian nursing students are more optimistic about their future given the fact that their average grade for those claims $(M=3.68)$ is higher than the average grade given by Croatian nursing students ( $M=3.51)$. By doing the t-test for large independent samples, a statistically significant difference has been found in 9 to 15 claims.

According to the available bibliography, there are few studies on the topic of temporal satisfaction. One of the studies in Croatia was conducted in 2006 in Zadar, Split, Šibenik and Sinj on an appropriate sample of participants in different age groups. Groups of high school pupils and college students were questioned in groups, while younger adults who do not attend college, middle-aged participants and older participants were contacted individually. The study included several groups of participants. Firstly, there was a group of younger adolescents (high school students) which was made up of 104 participants between the ages of 15 and 17. Secondly, a group of college students and younger adults which consisted of 145 participants between the ages of 18 and 29, out of whom most were college students from the Universities in Zadar and Split. This group also included younger adults who had finished their high school education and did not enrol in college but were employed or registered at the Croatian Employment Institute. A group of middle-aged participants consisted of 114 people between the ages of 30 and 49, while the group with older people had 120 participants aged between 50 and 71 (8).

A study concerned with life satisfaction (Penezić, 2006) attempted to determine the differences in satisfaction with life among different age groups from the same country. The assessments of past satisfaction were lowest for middle-aged people, while the expected satisfaction with the future was highest in younger adolescents. In our study we wanted to research temporal satisfaction with life between two groups of people of approximately the same age who study in different countries.

By comparing the results of the previous study (Penezić, 2006) with the results of our study, it can be concluded that a change has occurred in the satisfaction with life among groups of younger people. Although in 2006 a group of younger people gave the most points to claims regarding their satisfaction with the future, the group of younger people who participated in our study is most satisfied with their life in the present. Most of the students are at the end of their college education, and this fact could contribute to lower points for satisfaction with their future. Because of the fact that they are about to end their formal education and start their careers, which means that they will be forced to accept the work habits in their country, the participants, on average, gave 3.6 points for their satisfaction with future life $M=3.52$ for participants in Croatia and $M=3.68$ for participants in Bulgaria.

At the end of 2008, the world financial crisis manifested itself in Croatia, firstly by halting economic growth, then by cutting down production and spending and, finally, by lowering the GNP by $5.8 \%$. The financial crisis started in the USA and spread across the world, and is called "the first global financial crisis of the 21st century" (11). If we take into account the fact that the average age of Croatian participants was 22, that makes their age at the beginning of the crisis 11 years old. A possible reason for their average grade of 3.43 for past satisfaction could be the financial situation of the country.

In 2007, the Republic of Bulgaria joined the European Union. The country also experienced a series of economic problems that are reflected in a high percentage of the poor population (22\%) and unemployment rates of approximately $12 \%$ according to data collected in 2013. Although the highest percentage of the population is Bulgarian, the largest minority is Turkish (8.8\% in 2015) (12). Bulgarian students gave, on average, 3.72 points to claims regarding satisfaction with the past. The reason could be the fact that $34 \%$ of the participants does not have Bulgarian citizenship (41\% Russian, 41\% Turkish, 12\% Ukrainian and 6\% Belarusian). Growing up in an economi- 
cally more stable society (Russia, Turkey, Ukraine and Belarus) whose economy was not as affected by the crisis contributes to a higher average grade for claims regarding satisfaction with the past.

This study has certain methodological restrictions that could influence the results. It is necessary to point out how future studies on the same topic could be improved. The number of participants in this research is not indicative of the entire population of nursing students neither in Croatia nor in Bulgaria. The sample consisted of 100 nursing students, 50 from Croatia and 50 from Bulgaria. Future research should increase the number of participants. Furthermore, statistical analysis that can be done on this number of participants is restricted, and the results have to be taken with precaution. In this kind of study, the participants sometimes do not answer honestly but in a socially acceptable way. With these guidelines, future research should include other factors that can contribute to temporal satisfaction with life in nursing students, such as the distance between place of study and hometown, various family factors, marital status, health, the socio-economic situation the individual and their family, etc. Putting focus on life satisfaction in younger people is important in order that interventions can be steered towards improving positive indicators of wellbeing. Although this study is flawed, it is the first study in Croatia that dealt with differences in temporal satisfaction with life by taking into account where the nursing students live. In this way, it contributed to understanding the very concept of temporal satisfaction with life.

\section{Conclusion}

A statistically significant difference has been found in the average evaluations of 9 out of 15 claims. Furthermore, it can be concluded from the results that there is a statistically significant difference in the average evaluation of temporal satisfaction with life among nursing students from Croatia and Bulgaria. This leads to the conclusion that, in this case, the place of study affects the temporal satisfaction with life among nursing students.

\section{References}

1. Cummins RA, Andelman R, Board R, Carman L, Ferriss $A$, Friedman $P$, et al. Quality of life definition and terminology: a discussion document from the International Society for Quality of Life Studies. International Society for Quality of Life Studies. 1998;1-43.

2. Beutell N. Life Satisfaction in Relation to Work and Family. Sloan Work Family Researchers Network. Life satisfaction (in relation to work-family variables). Sloan Work-Family Encyclopedia. Boston College; 2006.

3. Ackerman CE. Life Satisfaction Theory and 4 Contributing Factors. Positive Psychology. 2018.

4. Veenhoven R. Quality of Life and happiness: not quite the same. In: de Girolamo G, Becchi A, Coppa FS et al, eds. Salute e qualità della vita. Torino: WHO and Centro Scientifico Editore, 2001:67-95.

5. Gokcen A, Aysegul E, Esra A. Psychometric properties of the Temporal Satisfaction with Life Scale among Turkish people. Psychiat Clin Psych. 2019;29(2):204-211.

6. Zlopaša K. Zadovoljstvo životom: sociološki pogled na primjeru studenata iz Jamajke [završni rad]. Zagreb: Sveučilište u Zagrebu, Fakultet hrvatskih studija; 2017. Available from: https://urn.nsk.hr/urn:nbn:hr:111:600104. Croatian.

7. Tuce Đ, Fako I. Odrednice zadovoljstva životom kod adolescenata. Psihologijske teme. 2014;23(3):407-33. Croatian.

8. Penezić Z. Zadovoljstvo životom u adolescentnoj i odrasloj dobi. Društvena istraživanja. 2006;15(45(84-85)):643-69. Croatian.

9. Europska unija. Živjeti u EU-u; 2017e. Available from: https://europa.eu/europeanunion/about-eu/figures/ living_hr\#tab-2-4 Accessed: 20.08.2017.

10. Diener E, Emmons RA, Larsen RJ, Griffin S. The Satisfaction With Life Scale. J Pers Assess. 1985;49(1):71-75.

11. Benolić M. Svjetska ekonomska kriza: razvoj, utjecaj na Republiku Hrvatsku i subjektivni stavovi studenata. Pravnik. 2012;46(92):119-38. Croatian.

12. Hrvatska gospodarska komora. Bugarska - država rastućih poslovnih mogućnosti. Hrvatska gospodarska komora. Available from: https://www.hgk.hr/documents/bugarska-drzava-rastucih-poslovnih-mogucnosti-011220165849665640e14.pdf. Croatian. 


\section{USPOREDBA TEMPORALNOG ZADOVOLJSTVA ŽIVOTOM STUDENATA SESTRINSTVA REPUBLIKE HRVATSKE I REPUBLIKE BUGARSKE}

\section{Sažetak}

Uvod. Temporalno zadovoljstvo životom može se definirati kao zadovoljstvo pojedinca prošlim, sadašnjim i budućim životom. Kako bi se smanjila potencijalna pogreška mjerenja zadovoljstva životom, u klasično istraživanje zadovoljstva životom stavlja se fokus na različita životna razdoblja. Usko uz pojam zadovoljstva životom veže se pojam sreće koja predstavlja trenutačno, prolazno iskustvo; iako je ugodno, može se dogoditi da traje duže ili kraće. Zadovoljstvo životom, s druge strane, mnogo je kompleksniji pojam, odnosno brojni autori definiraju ga kao opći osjećaj o životu pojedinca. Postoji mnogo čimbenika koji pridonose zadovoljstvu životom s brojnih područja, uključujući posao, romantične veze, odnose s obitelji i prijateljima, osobni razvoj, zdravlje te mnoge druge faktore. Mjere zadovoljstva životom općenito su subjektivne ili se temelje na varijablama koje pojedinac smatra osobno važnima u vlastitom životu.

Cilj. Ispitati i usporediti razlike u temporalnom zadovoljstvu životom studenata sestrinstva Republike Hrvatske i Republike Bugarske.

Metode. U istraživanje je bilo uključeno ukupno 100 studenata sestrinstva, od čega 50 ispitanika studira sestrinstvo u Republici Hrvatskoj, a 50 u Republici Bugarskoj. U istraživanju se kao instrument ispitivanja primijenio anketni upitnik Skala temporalnog zadovoljstva životom (Temporal Satisfaction with Life Scale, dalje u tekstu TSWLS), koju su 1998. godine osmislili Pavot i suradnici.
Rezultati. Pronađena je statistički značajna razlika u ocjenama devet od 15 tvrdnji. Nadalje, statistički značajna razlika vidljiva je u prosječnoj ocjeni ukupnoga temporalnog zadovoljstva životom između studenata sestrinstva iz RH i RB.

Zaključak. Istraživanjem su utvrđene statistički značajne razlike u temporalnom zadovoljstvu životom studenata sestrinstva iz Republike Hrvatske i Republike Bugarske.

Ključne riječi: temporalno zadovoljstvo životom, studenti sestrinstva, mjesto studiranja 